\title{
Effectiveness and therapeutic safety using $\beta$-tricalcium phosphate in oral bone defects
}

\author{
Mayra de la Caridad Pérez Álvarez ${ }^{1,2 *}$, José Ángel Delgado García-Menocal ${ }^{2}$, Daisy M. Márquez Argüelles ${ }^{1}$, Lubenia García Rodríguez ${ }^{3}$, \\ Gastón Fuentes Estévez ${ }^{2}$, Josefa Morejón Álvarez ${ }^{4}$, Juan Carlos Hernández Varea ${ }^{5}$, Jorge Hernández Cruz ${ }^{6}$, Rosa Mayelín Guerra Bretaña ${ }^{2}$, \\ Amisell Almiral La Serna ${ }^{2}$, Alexeis Beltrán Alfonso ${ }^{1}$, Adrián Alfonso Hernández ${ }^{2}$ and Martha Luisa Pérez Pasos ${ }^{5}$ \\ ${ }^{1}$ Department of Oral Surgery, University Dental Clinic, Bauta, Artemisa 32600, Cuba \\ ${ }^{2}$ Department of Ceramics and Metallic Biomaterials, Biomaterials Center, University of Havana, La Habana 10400, Cuba \\ ${ }^{3}$ Department of Comprehensive General Stomatology, "Raúl González Sánchez “ University Dental Clinic, San Antonio de los Baños, Artemisa 32500, Cuba \\ ${ }^{4}$ Department of Maxillofacial Surgery, "Leon Cuervo Rubio” Hospital, Pinar del Río, Cuba \\ ${ }^{5}$ Department of Comprehensive General, National Centre of Stomatology (CENAEST), La Habana 10400, Cuba \\ ${ }^{6}$ Department of Maxillofacial Surgery, "Faustino Pérez" Hospital, Matanzas, Cuba
}

\begin{abstract}
Aim: To determine the effectiveness and therapeutic safety with $\beta$-tricalcium phosphate (Biograft- $\left.\mathrm{G}^{\circledR}\right)$ in oral bone defects.

Methods: A Phase III, multicenter, uncontrolled clinical trial (Classification of medical devices), to assess the Biograft-G ${ }^{\circledR}$ Biomaterials Center, University of Havana was made. All the population of the clinical trial was choose from four Cuban provinces and 121 patients was the sample selected for the studies. All the patients gave their consent to participate. The patients included in the study were: ages between 18 and 75 years, both sexes that could be treated surgically. Patients with malignant neoplasms of any location, diabetic patients who were decompensated or difficult to control, immunosuppressed or immunosuppressed, and mentally retarded patients were excluded. Surgeries were performed in patients requiring dental extraction, alveolar ridge reconstruction, periodontal and periapical surgery. The main variable was a clinical and radiographic appearance, evaluated in four periods (7 days, 1, 3 and 6 months) and levels: Success and Failure.

Results: An effectiveness of $97.5 \%$ for $\beta$-tricalcium phosphate (Biograft- $\mathrm{G}^{\circledR}$ ) was demonstrated. In all the periods of clinical and radiographic evaluation of it showed gradually reabsorption similar to surrounding healthy tissue, until the complete degradation of the biomaterial. It was determined that adverse treatment (infection, delamination of the material, tenderness and pain) events behaved low.
\end{abstract}

Conclusion: It was concluded high effectiveness and safety of treatment with Biograft- $\mathrm{G}^{\circledR}$ in complex oral surgery, with minimal and mild adverse events to treatment.

\section{Introduction}

The bone is classified as a specialized connective tissue consisting of inorganic and organic substances, which give properties such as hardness and elasticity. These tissue influence in a normal bone physiology because it involves a complex interaction between blood minerals (specially calcium and phosphorus), regulation of certain hormones, the activity of bone cells (osteoblasts and osteoclasts) and tensile forces and stretching own body [1].

When the bone tissue of the maxilla or mandible is damaged, it regenerates spontaneously. However, healing is a slow process that can be improved by applying different Biomaterials [1,2].

The dental alveolus is the holes that support the teeth and these cause that it is a special portion of the oral human bone very studied by scientists. As in other bone sites, alveolar bone depends on the functional stimulation of the teeth to maintain their morphology. The remodeling of the aforementioned holes occurs with new bone when the dental organs are lost. The way to do this restoration is called alveolar ridge and it is provide a certain height and thickness. When remodeling occurs spontaneously usually atrophic alveolar ridges (AAR) are obtained that cause difficulties for prosthetic rehabilitation [3-5]. Just this fact justifies the use of surgical techniques and implantable materials, bone substitutes and roots, to remodel the alveolar ridge and prevent their reabsorption [4-7]. It is important that biomaterials used in the surgical process be biocompatible, non-toxic, non-carcinogenic or mutagenic, have good mechanical properties and be tolerated in the short, medium and long term.

Among the mentioned materials are hydroxyapatites (HA) and $\beta$-tricalcium phosphate (TCP), which have proven welfare and safety in many biomedical specialties $[1,8,9]$. The hydroxyapatites interact with the adjacent bone tissue acting as matrix on which is deposited the newly formed bone, high hardness and the stability that provides a mechanical reinforcement of repaired bone [7,10-13]. However, the excellent clinical results reported, it is recognized that the repaired bone is extremely resistant to carving, being a disadvantage for those

Correspondence to: Mayra de la Caridad Pérez Álvarez, Departamento de Cirugía Bucal, Clínica Estomatológica Docente de Bauta, Artemisa 32600, Cuba, Tel: +53-047374197; Email: mayra@biomat.uh.cu

Key words: bone rehabilitation, $\beta$-tricalcium phosphate, biograft- $G^{\circledR}$, reabsorbible biomaterials

Received: November 14, 2016; Accepted: December 11, 2016; Published: December 14, 2016 
cases where you can place metal implants [14-16].

This property increases the use of resorbable materials such as TCP whose main attraction is that the implanted material is degraded at a rate that allows it to be replaced by a bone tissue with radiographic and histological appearance similar to the neighbor tissues [17-21]. On this background, the Biomaterials Center at the University of Havana (BIOMAT, Cuba) has developed a biodegradable and implantable ceramic (four different size granules) for bone repair, based on $\beta$-TCP, called Biograft- $\mathrm{G}^{\circledR}$. The chemical-physical and preclinical evaluations have demonstrated its high quality, with no evidence of adverse reactions [22]. For these reasons a clinical study to demonstrate the effectiveness and safety of treatment with Biograft- $G^{\circledR}$ in the repair of the oral bone complex was done.

\section{Methods}

Phase III (Medical Classification of medical devices) clinical, multicentric, uncontrolled research, with bone lesions suitable for applying Biograft- $G^{\circledR}$ as filler, was performed. The universe of study was the population of four provinces of Cuba and the sample contained 121 patients from five health institutions who met inclusion criteria, exclusion and diagnosis (retained or incurable teeth indicated for extraction, periodontal and periapical alveolar ridge reconstruction atrophic surgery) in the period from February 2010 to February 2015. In Figures 1 and 2 it is shown clinical and radiographically one tooth for extraction due to root fracture.

Prior to inclusion, all patients were given the specifications of the treatment, which was part of informed consent. In cases of acceptance, a document was signed by the patient and the investigator. From the methodological, scientific and ethical point of view, the research project

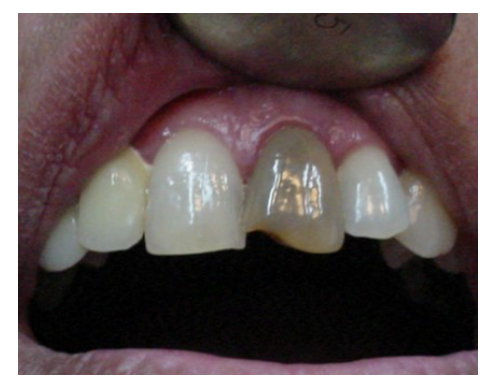

Figure 1. Tooth extraction indicated.

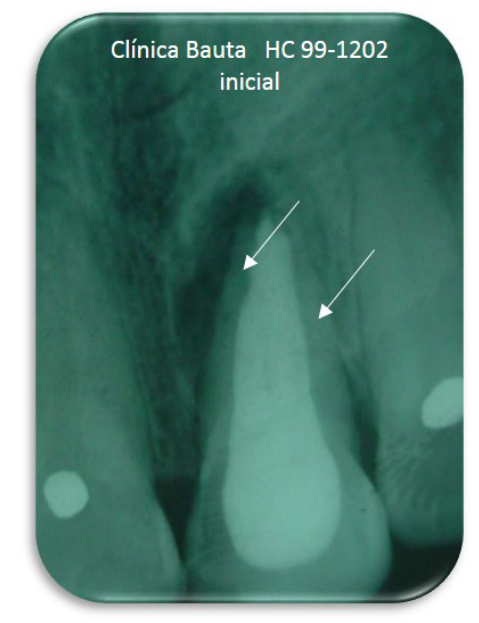

Figure 2. X-rays of root fracture. was reviewed, evaluated and approved by the Ethics Committee of each participating institution and by the Review Committee created for this clinical research at the coordinating institution, University Dental Clinic of Bauta, Artemisa. All patients had Data Collection Notebook (DCN) which included general patient information, informed consent, number, condition and type of surgical process, as well as all evaluations completed.

The inclusion criteria were age ranges between 18 and 50 years, both sexes, Cuban citizens regardless of race, who gave writing consent to participate, following the Helsinki's principles and the bioethics rules that governing clinical investigations [23,24]. It excluded patients with habits (tobacco and alcohol), difficult to control diabetics, immunosuppressed, mentally retarded, pregnant women and individuals who refused inclusion. It was excluded too the patients was interrupted them implantation surgery or who did not attend the evaluations were applied.

The biomaterial used named Biograft- $G^{\circledR}$ was manufactured by Biomaterials Center, University of Havana, Cuba in form of resorbable, synthetic, dense, ceramic $\beta$-TCP granules. The biomaterial was defined as implantable medical devices, Class II b, with Certificate of Registration (Code 87 LMN), at Center for the State Control of Medicaments, Equipment and Medical Devices (CEDMED), Ministry of Public Health, Cuba and the study is registered in the Cuban Clinical Trials Public Registry [25]. The Biograft- $G^{\circledR}$ is a $\beta-\mathrm{TCP}$ (with purity crystalline tricalcium phosphate) $95 \%$ minimum, granulate, white, with molar ratio $\mathrm{Ca} / \mathrm{P}=1.50$, stored in a cool dry place, and sterilized by dry heat or autoclave. The drugs used in the clinical study were with Lidocaine $2 \%$ with epinephrine anesthetic (Liorad Laboratories, Cuba) and Dipyrone (Medsol Laboratories, Cuba).

The application of Biograft- $G^{\circledR}$ was conducted after obtaining a bone site carefully clean, following of the conventional techniques of each intervention (Figure 3). The granulates were soaked with blood from the surgical site, and implanted into the prepared cavity, from the defect's depths to the access port (Figure 4).

This procedure is performed under gentle pressure on the Biograft- $G^{\circledR}$ cover by a collagen membrane (Membracel-O, Celina Laboratories, Argentine) which it was placed to allow guided tissue

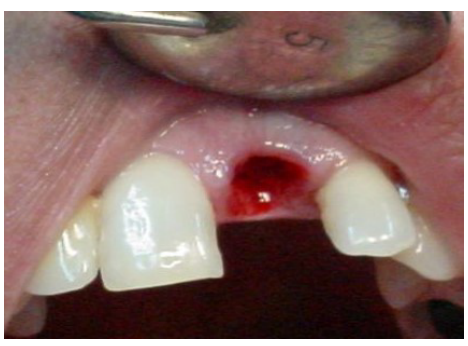

Figure 3. Surgical site carefully clean.

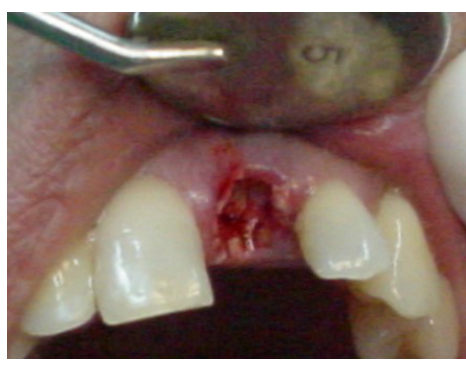

Figure 4. Biograft-G grains in surgical site. 
regeneration (Figure 5). The union of the soft tissue was performed with sutures (Silk 3.00) or Tisuacryl ${ }^{\circledR}$ tissue adhesive (BIOMAT, Cuba) like it shows at figure 6 . The suture has to be removed between 7 and 15 days. The Tisuacryl ${ }^{\mathbb{B}}$ doesn't have to be removed.

\section{Results}

The response within seven days of treatment was shown in Table 1 where $12 / 121$ patients $(9.9 \%)$ had Regular evaluation. This is explained, because it is invasive treatments to soft tissue, described with similar response in other studies [15]. However, in radiographic evaluation all patients were success (more than $90 \%$ of biomaterial displayed), indicating a correct filling.

One month after the treatment (Table 2), it could see that $11 / 12$ patients went to good evaluation and radiographic changes did not exist. This fact match with Trisi [17] who observed radiopacity at same time period, with minimal integration aspect. Von Doernberg also [20] suggested that in resorbable materials, a healing is observed when radiopacity is decreasing and replaced by new bone. García-Roco [25] also agrees with previous in visualize radiographically stable all the restorations if it find radiopaque areas and disappearance of the difference between the material and the adjacent bone. The Failure case

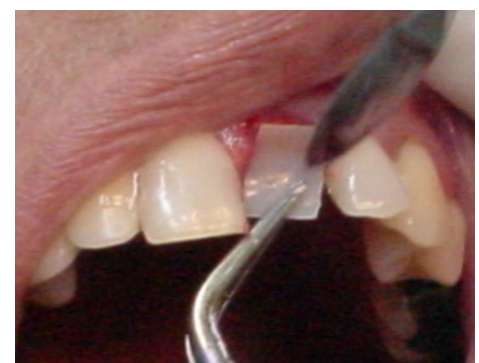

Figure 5. Collagen membrane.

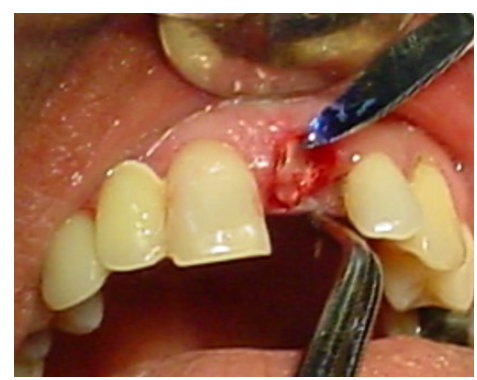

Figure 6. Tisuacryl in surgical site.

Table 1. Clinical and radiographic response at 7 days.

\begin{tabular}{|l|c|c|c|c|c|}
\hline Clinical & Freq. & $\mathbf{\%}$ & Radiographic & Freq. & $\mathbf{\%}$ \\
\hline Good & 108 & 89.3 & Success & 120 & 99.2 \\
\hline Regular & 12 & 9.9 & Failure & 0 & 0 \\
\hline Bad & 0 & 0 & Lost & 1 & 0.8 \\
\hline Lost & 1 & 0.8 & Total & 121 & 100 \\
\hline Total & 121 & 100.0 & & & \\
\hline
\end{tabular}

Absolute frequency $=$ Freq. Percentage $=\%$

Table 2. Clinical and Radiographic response to one month.

\begin{tabular}{|l|c|c|c|c|c|}
\hline Clinical & Freq. & $\mathbf{\%}$ & Radiographic & Freq. & \% \\
\hline Good & 118 & 97.5 & Success & 119 & 98.3 \\
\hline Regular & 1 & 0.8 & Failure & 1 & 0.8 \\
\hline Bad & 1 & 0.8 & Lost & 1 & 0.8 \\
\hline Lost & 1 & 0.8 & Total & 121 & 100.0 \\
\hline Total & 121 & 100.0 & & & \\
\hline
\end{tabular}

was a patient who presented infection and pain in alternative 2-3 days periods during a month. It was decided to remove the material and categorizing as a Failure, although it was not related to biomaterial, because it was a traumatic extraction. Regular response was due to a nasal polyp near the surgical site. The remaining patients $(97.5 \%)$ were assessed as Good, because at this stage had already passed the time of surgical trauma.

At 3 months (Table 3) the response was that 116/121 patients (95.9\%) were evaluated as Success from clinical and radiographic point of view. The patients evaluated as Bad can be described as one corresponded to a worsening of clinical symptoms of nasal polyp above mentioned, although it was radiographically successful, it was necessary to indicate a treatment to improve the change made ear-nose and throat. The second patient presented a vestibular fistula with pus out on a tooth from the surgical stage and it was detected poor condition of the root surface. A radiographic evaluation of TCP granulates showed that $70 \%$ is observed without reabsorb, but with little radiographic contrast. The patient evaluated as Regular was reflected as a pain caused by slight dentinal hyperesthesia, with no significant inflammation of the gums.

The clinical and radiographic responses at 6 months are shown in Table 4. It was observed that $97.5 \%$ of patients were recovered. The patient who presented the nasal polyp was listed as successfully cured. Failure by fistula and infection, was treated and to perform the extraction was again included in the study, presented satisfactory evolution without reaction to the implanted biomaterial, Biograft- $G^{\circledR}$.

Regarding the existence of filler in the bone cavity (Table 5), at 7 days can be observed an average of $96 \%$, a proper filling of the defects (Figure 7). Similar evolution is observed after one month, verifying the absence of exfoliation (Figure 8).

At 3 months it shows that the material remains on average by $73 \%$ without radiolucency appear, which corresponds to the expected resorption (Figure 9). At 6 months, the presence of the material had the average value $44 \%$, indicating that the resorption continues (Figure 10).

Lozada [16] raised similar situation after three weeks, a dense connective tissue and newly formed bone trabeculae, which persists after three months until to 12 months when there is a new formation

Table 3. Clinical and Radiographic response at three months.

\begin{tabular}{|l|c|c|c|c|c|}
\hline Clinical & Freq. & $\mathbf{\%}$ & Radiographic & Freq. & \% \\
\hline Good & 118 & 95.9 & Success & 118 & 97.5 \\
\hline Regular & 1 & 0.8 & Failure & 2 & 1.6 \\
\hline Bad & 3 & 2.5 & Lost & 1 & 0.8 \\
\hline Lost & 1 & 0.8 & Total & 121 & 100 \\
\hline Total & 121 & 100.0 & & & \\
\hline
\end{tabular}

Table 4. Clinical response, and radiographic at six months.

\begin{tabular}{|l|c|c|c|c|c|}
\hline Clinical & Freq. & $\mathbf{\%}$ & Radiographic & Freq. & $\mathbf{\%}$ \\
\hline Success & 118 & 97,5 & Success & 118 & 97,5 \\
\hline Failure & 2 & 1,6 & Failure & 2 & 1,6 \\
\hline Lost & 1 & 0,8 & Lost & 1 & 0,8 \\
\hline Total & 121 & 100,0 & Total & 121 & 100 \\
\hline
\end{tabular}

Table 5. Descriptive statistics (\% filler).

\begin{tabular}{|l|c|}
\hline Radiological Response & Mean \pm SD (\%) \\
\hline 7 days & $95.6 \pm 0.4$ \\
\hline 1 month & $94.9 \pm 0.5$ \\
\hline 3 months & $73 \pm 1$ \\
\hline 6 months & $44 \pm 2$ \\
\hline
\end{tabular}




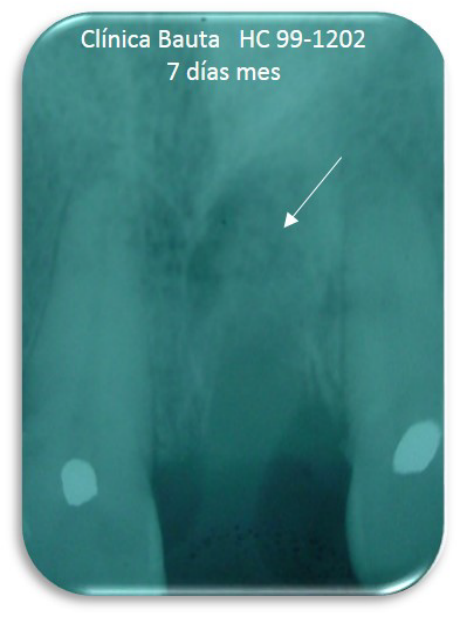

Figure 7. Seven days

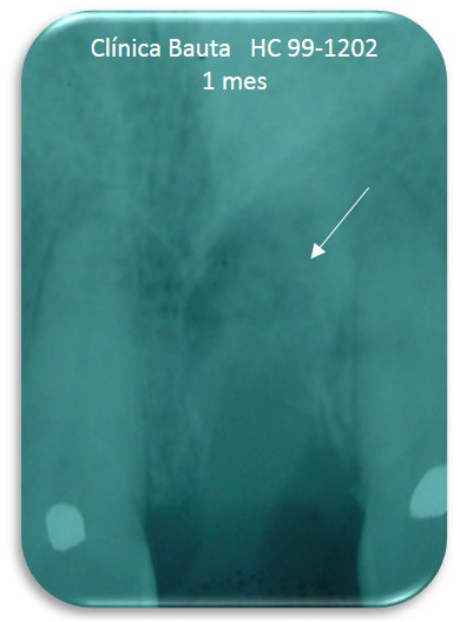

Figure 8. One month.

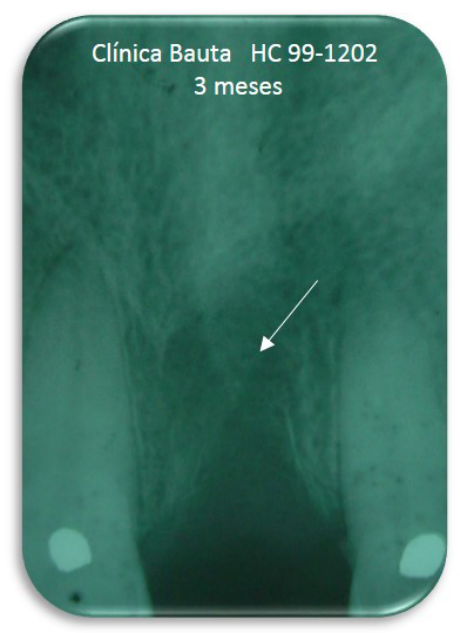

Figure 9.Three months.

and complete resorption of the material is observed.

In Table 6, it shows the final result of the study with $97.5 \%$ of effective use of the material considering the failure not attributable to biomaterial, which not demonstrates serious adverse events in the

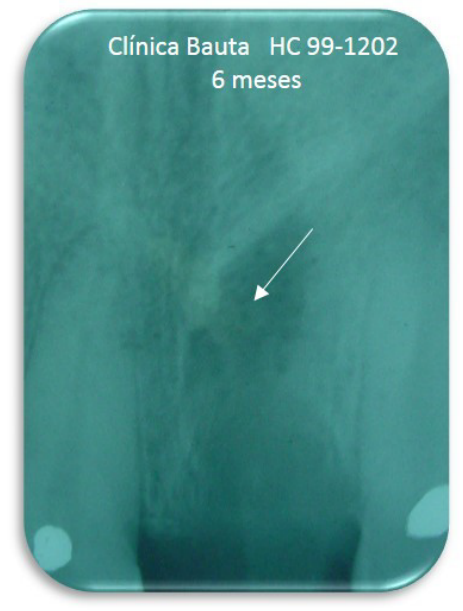

Figure 10.Six months.

Table 6. General Effectiveness.

\begin{tabular}{|l|c|c|}
\hline Effectiveness & Frequency & Percent \\
\hline Success & 118 & 97.5 \\
\hline Failure & 3 & 2.5 \\
\hline Total & 121 & 100.0 \\
\hline
\end{tabular}

treated cases. These satisfactory results are consistent with studies like Aguirre [26] which noted favorable tissue response implants. All these elements allowed him to infer that the $\beta$-TCP can be evaluated as nontoxic locally, with no inflammation or foreign body response in the tissue. A similar view is reflected by Delgado et al, on the implantation of Biograft $\mathrm{G}^{\circledR}$ response [22].

Biograft- $G^{\circledR}$ showed a high effectiveness in the treatment which are consistent with other studies of the authors $[14,17]$ and demonstrate the importance of reabsorbable biomaterials to fill the spaces where the bone structure could be lost and lead to the growth of a new bone while it is degradated. Other authors like Simunek, [18], consider achieve preservation of the width of the tooth socket. Mayer [19] also suggested that these techniques are able to maintain a good level of bone volume by preventing bone resorption of the alveolar ridge.

\section{Conclusion}

It was determined that Biograft- $\mathrm{G}^{\circledR}$ had high effective $(97.5 \%)$ and safe in oral bone defects. In periods where the evaluation was tracked, clinical and radiographic responses was positive in most patients. Furthermore, they managed advantages in obtaining a newly formed bone tissue similar to nearby normal tissue.

\section{Acknowledgements}

Authors thank the financial support of the Cuban Ministry of Health and of the University of Havana, Cuba.

\section{References}

1. Suárez D (2012) Principios básicos en regeneración ósea guiada. Rev Acta Clínica 2: 89-116.

2. Ford-Martinelli VL, Hanly G, Valenzuela J, Herrera-Orozco LM, Muñoz-Zapata S (2012) Alveolar ridge preservation? Decision making for dental implant placement. Rev CES Odont 25: 44-53.

3. Hämmerle CH, Araújo MG, Simion M (2011) Evidence- based knowledge on the biology and treatment of extraction sockets. Clin Oral Implants Res 23: 80-82. [crossref] 
4. Pato Mourelo J, Jiménez Guerra A, Monsalve Guil L, Segura Egea JJ, Velasco Ortega E (2010) Regeneración ósea guiada con implante unitario con nanosuperficie y beta fosfato tricálcico. Av Periodon Implantol 3: 127-134.

5. Sánchez Garcés MA, Vilchez Pérez MA, Cortell Ballester I, Núñez Urrutia S, Sala Pérez S, et al. (2010) Revisión bibliográfica de Implantología Bucofacial del año 2008: Primera parte. Av Periodon Implantol 22: 91-107.

6. Saffar JL, Lasfargues JJ, Cherruau M (1997) Alveolar bone and the alveolar process: the socket that is never stable. Periodontol 2000 13: 76-90. [crossref]

7. Morejón Álvarez T, Morejón Álvarez F, López Benítez H (2000) Aplicación de la hidroxiapatita como material de implante en la profilaxis de la reabsorción alveolar. Rev C Pinar del Río 4: 1.

8. Peleg M, Garg AK, Mazor Z (2006) Predictability of simultaneous implant placement in the severely atrophic posterior maxilla: A 9-year longitudinal experience study of 2132 implants placed into 731 human sinus grafts. Int J Oral Maxillofac Implants 21: 94-102. [crossref]

9. Al Ruhaimi KA (2001) Bone Graft Substitutes: A comparative Qualitative Histologic Reviewof Current Osteoconductive Grafting Materials. Int J Oral Maxillofac Implants 16: $105-114$.

10. García D, García L, Pérez MP, Suarez M, Delgado JA, et al. (2001) Filling of PostExtraction Dental Socket with Hydroxyapatite Granules APAFILL-G. Key Engineering Materials Trans Tech Publications 2001 192: 925-928.

11. Yépez y Col (2015) Relleno de defecto óseo postquirúrgico con hidroxiapatita: reporte de un caso. Acta bioclínica 5: 47-55.

12. Quintana JC, Rodriguez R, Cruz AH (2004) Empleo de la hidroxiapatita en la reparación ósea periapical. Rev Cubana Estomatol 41: 3.

13. Pérez Álvarez MC, Delgado García-Menocal JA, Almirall La Serna, Alfonso HA, Collins J, et al. (2013) Use of Cuban Granulated ?-Tricalcium Phosphate "Biograft-G" as Maxilar Bone Graft. Oral Hyg Health 1: 103.

14. Pérez MC, Fernandez MI, Collins J, Rodriguez JA, Gracia R, et al. (2011) Comportamiento óseo de alveolos dentarios implantados con Biograft- $\mathrm{G}^{\mathrm{B}}$. Evolución de casos a los 6 meses. V Latin American Congress on Biomedical Engineering CLAIB 2011 33: 156-159.

15. Pérez MC, Delgando JA, Alfonso A, Guerra RM, Rodriguez JA, et al. (2014) Preprosthetic Remodeling of Alveolar Ridge Using Calcium Phosphate Biomaterials. VI Latin American Congress on Biomedical Engineering CLAIB 2014 49: 208-210.

16. Lozada P (2015) Aplicación de Beta Fosfato Tricálcico en alvéolos post extracción para evitar reabsorción ósea en pacientes de 40 a 60 años.

17. Trisi P, Rao W, Rebaudi A, Fiore P (2003) Histologic effect of pure-phase betatricalcium phosphate on bone regeneration in human artificial jawbone defects. Int $J$ Periodontics Restorative Dent 23: 69-77. [crossref]

18. Simunek J (2011) Estudio de la aplicación clínica del beta-fosfato tricálcico 115: 909-915.

19. Mayer Y (2012) Tratamiento del alveolo dental post-extracción. Odontólogo Moderno. 8: $2-3$.

20. von Doernberg MC, von Rechenberg B, Bohner M, Grünenfelder S, van Lenthe GH, et al. (2006) In vivo behavior of calcium phosphate scaffolds with four different pore sizes. Biomaterials 27: 5186-5198. [crossref]

21. Delgado Fernández R, Urbizo Vélez J, Rodríguez Sosa V, Rodríguez EI (2010) Evaluación de la respuesta hística del beta fosfato tricálcico (Biograft-G) como implante óseo. Rev Cub Estomatol 47: 124-33.

22. Declaración de Helsinki de la AMM (2013) Principios éticos para las investigaciones médicas en seres humanos. $64^{\mathrm{a}}$ Asamblea General, Fortaleza, Brasil.

23. Siurana AJC (2010) Los principios de la bioética y el surgimiento de una bioética intercultural. Veritas 22: 121-57.

24. Registro Primario de la OMS. Registro Público Cubano de Ensayos Clínicos.

25. García-Roco Pérez O (2002) Evolución en el tratamiento de la atrofia alveolar. Rev Cub Estomat 392: 55-58.

26. Aguirre Zorzano M (2012) El cambio de pronóstico con tratamiento regenerativo. Gaceta Dental 2012: 98-100.

Copyright: (C2016 Pérez Álvarez MC. This is an open-access article distributed under the terms of the Creative Commons Attribution License, which permits unrestricted use, distribution, and reproduction in any medium, provided the original author and source are credited. 